\title{
The Breathing Body, Whistling Flute, and Sonic Divine: Oneness and Distinction in Bengal Vaishnavism's Devotional Aesthetics
}

\author{
Sukanya Sarbadhikary
}

check for updates

Citation: Sarbadhikary, Sukanya. 2021. The Breathing Body, Whistling Flute, and Sonic Divine: Oneness and Distinction in Bengal Vaishnavism's Devotional Aesthetics. Religions 12: 743. https://doi.org/10.3390/ rel12090743

Academic Editor: Guy Beck

Received: 28 July 2021

Accepted: 4 September 2021

Published: 9 September 2021

Publisher's Note: MDPI stays neutral with regard to jurisdictional claims in published maps and institutional affiliations.

Copyright: (C) 2021 by the author. Licensee MDPI, Basel, Switzerland. This article is an open access article distributed under the terms and conditions of the Creative Commons Attribution (CC BY) license (https:// creativecommons.org/licenses/by/ $4.0 /)$.
Department of Sociology, Presidency University, Kolkata 700073, West Bengal, India; sukanya.soc@presiuniv.ac.in or sarbadhikary@gmail.com

\begin{abstract}
This paper studies complex narratives connecting the Hindu deity Krishna, his melodious flute, and the porous, sonic human body in the popular devotional sect, Bengal Vaishnavism. From the devotee-lover responding to Krishna's flute call outside, envying the flute's privileged position on Krishna's lips, to becoming the deity's flute through yogic breath-sound fusions-texts abound with nuanced relations of equivalence and differentiation among the devotee-flute-god. Based primarily on readings of Hindu religious texts, and fieldwork in Bengal among makers/players of the bamboo flute, the paper analyses theological constructions correlating body-flute-divinity. Lying at the confluence of yogic, tantric, and devotional thought, the striking conceptual problem about the flute in Bengal Vaishnavism is: are the body, flute and divinity distinct or the same? I argue that the flute's descriptions in both classical Sanskrit texts and popular oral lore and performances draw together ostensibly opposed religious paradigms of Yoga (oneness with divinity) and passionate devotion/bhakti (difference): its fine, airy feeling fusing with the body's inner breathing self, and sweet melody producing a subservient temperament towards the lover-god outside. Flute sounds embody the peculiar dialectic of difference-and-identity among devotee-flute-god, much like the flute-lip-lock itself, bringing to affective life the Bengal Vaishnava philosophical foundation of achintya-bhed-abhed (inconceivability between principles of separation and indistinction).
\end{abstract}

Keywords: flute; Bengal Vaishnavism; yoga; tantra; devotion; aesthetics; sacred sound

\section{Introduction}

\subsection{The Conceptual Problem}

A large majority of Hindu Bengalis are worshippers of the deity Krishna, whose indispensable accompaniment is the sweetest-sounding bamboo flute, said to draw his lover-devotees' hearts irresistibly towards him. ${ }^{1}$ This paper studies theological, aesthetic, and devotional Hindu texts (and practices) dedicated to the flute, and analyses complicated relationships posited among the devotee, flute, and Krishna. For instance, the instrument is represented as indistinguishable from Krishna, sticking to his lower lip and passionately attracting his other, the devotee; similarly, the devotee, as envying the flute's privileged position and desiring to become it, and further, embodying its empty sounding through yogic processes of ego relinquishment and cultivation of subtle sonorous interiority, Krishna thus becoming the other of the devotee-flute; or the devotee-as feminine potentialuniting with Krishna - the cosmic male energy - and the body then resounding the flute during these intense moments of erotic union. In all these varied instances, there are most immediate embodied relations imagined between the devotee's inner breath and divine flute sounds, breath fusing into, and indeed, becoming sound. I shall explore the textual weavings of these body-flute, breath-sound, devotee-god imaginations, and study discursive practices of constructing the yogic body as a singing mirror of Krishna's breathinstrument, flute. Such relatedness is constructed through different ideas of their material anatomical constitutions: varied classifications of number of holes in the body/flute, the 
phenomenology of airing inside, and the flute sound's semblance with corporeal aurality (produced through spinal energy centres or chakras), and the nasal vocal hum.

While Krishna playing the flute is an absolute mainstream and heavily represented Hindu symbol, its possible esoteric/yogic dimensions of sonic divination, and their links with popular devotion, have not been adequately studied. Natural, bodily, and instrumental sacralities are embroiled in this sound-universe, and 'tuning in the sacred', in this context, thus has significant implications in imagining the body as flute. While developments in yogic thought shall be critical for the paper, its focus shall be on theories, practices, and oral lore of a significant religious sect, the Bengal Vaishnavas, who worship Krishna in the devotional mood of his women lovers in the cosmic abode, Vrindavan.

Bengal Vaishnavism began as one of the most significant collective devotional movements of North India in the sixteenth century, with the ultimate aim of realising divine erotic love between the deity couple Radha-Krishna. The intense religiosity was spearheaded by the saint Chaitanya (1486-1533), himself worshipped as the dual incarnation of Krishna and his lover-consort, Radha, in the same body. The philosophical import of Bengal Vaishnavism lies in its mediation between the Advaita doctrine of pure monism, where god and individual soul are the same, and the Dvaita precept of pure dualism, where they are different. The sect rather cultivates the compelling idea of achintya-bhed-abhed, or inconceivable difference and sameness, between the supreme divine, Krishna, and his entire devotional world.

Body-flute resemblances begin with nature. The flute's light nasal tonality viscerally connects with the cuckoo-bird-like whistling hum of human voice, and this flesh continuum between the body and flute has other images of origin too. ${ }^{2}$ Thus, a bamboo pipe with insect-holes lies idly in a bamboo forest, its layered insides hissing empty and nasal sounds in tune with variously paced wind gushes, a favourite image of the classical poet, Kalidasa (Krishnaswamy 1965, p. 9; Deva 1977, p. 73), and a body breathes through its pores in different pulses, and produces congruent sounds/speech. These are involuntary states of air/sound, which can be honed through voluntary acts of controlled breathing. Such cultivation involves a superintending consciousness: thus, the (divine) flutist knows how to strike the right notes in the bamboo flute through the ideal balance of breath, fingering, and tonal intuition. Similarly, yogic discourses assert that with correct bodily postures and breathing patterns (pranayama), the yogi-subject attunes to an inner spiritual soundscape, which when concentrating in the cranium, sounds the entire body as a porous, whistling flute. The ghostly aloneness of rural nocturnal bamboo forests with their hollow sounds of fresh bamboo leaves falling on dry ones, generated as if by divine breath-air, thus essentially ties with the meditative deftness of solitary yogi flautists and their breathing viscera. The devotee may either want to extend his inner sonic/devotional potential by making/blowing on a flute, their air sounds merging in devotion to Krishna, or conversely, to tune one's own body as Krishna's beloved flute, corporeal breath then culminating in divine acoustics.

The body-flute notion generally follows the porosity and fluidity of dividual and permeable Hindu bodies, identified by Mckim Marriott. Rather than the western individualist paradigm separating the subject from object, nature-culture, materiality-morality, and mind-sensation are tied in a singular, 'monist' philosophical cosmos involving the body and the instrument (Marriott 1976, p. 109; 1989, pp. 2-17). The yogic body and flute's sound thus flow into each other, and even as each other, in a 'moving' (jagat) and 'flowing' (samsara) devotional world, both perceptually and conceptually (see Marriott 1989, pp. 18-22). Therefore, I follow Marriott's strong suggestion of instituting productive ethnosociologies which seriously explore the monism of Hindu thought, or the incessant flows between gross and subtle levels of inherently divisible bodies (Marriott 1976, pp. 110-38), in this case, between corporeality, breath, and sound.

The striking conceptual problem in the discursive scheme of this particular religious system, and paper, however, is: when the body becomes the flute, do their superintending consciousness(es) merge or remain distinct? Is the yogi's conscious breathing centre 
imagined as Krishna himself, or does the body-flute receive Krishna's breath from outside? If the body becomes the flute, and the flute adheres to Krishna, then does the body embody the divine? Or does the body-flute draw towards the deity Krishna outside? Simply, does the devotee become Krishna, or remain separate? Classical and popular devotional songs are replete with references to Krishna's flute as the ideal romantic icon pulling his discrete lover-devotees close, while Yoga texts deem hearing inner flute sounds as signs of achieving higher spiritual states. While both sameness and distinction between the devotee, flute, and god are reflected amply in these textual representations, I argue that the flute's material constitution and timbre itself also draws together the ostensibly opposed religious paradigms of Yoga (oneness with divinity) and devotion/bhakti (difference from divinity): its lightweight experience fusing with the body's inner breathing self, and its sweet melody producing a soft, subservient temperament in the listener, directed towards the lover-god outside. These apparently diverse associations lead to a complex religious terrain in which the yogic/devotional body is modeled after the flute, the flute is considered a body in its own right, and further, the body-flute is both same/different as/from Krishna.

The body as flute idea stems from yogic and tantric understandings of sound (the AUM buzz) - discussed below - as the primordial causal vibration, embodying divine breath, and resulting from the union of cosmic male-female energies. AUM is believed to constitute and materialise all sentient life: including a devotee's breath interiors which resonate divine instruments. More than any other such instrument, the flute is essentially dependent on the flautist's inner corporeal constitution: breath, and its conscious control and release. Equally critical is the intuition involved in playing flute notes, involving the balance of fingers and breath. The tune has to be literally sensed/seen/heard mentally before being played physically. All these phenomenological dimensions bring together the seemingly contrasting categories of mind and body, Yoga and bhakti, thought and feeling, within the flute paradigm.

\subsection{The Textual Matter}

This paper is primarily based on textual readings ranging from classical religiousaesthetic discourses in the Natya Sastra (2nd century CE), to understandings of bodily regimens of sound meditation in Bhagavad Gita (3rd century CE), early Yoga Upanishads (100-300 CE), later medieval Yoga texts, to devotional tracts of Bhagavata Purana (900 AD), especially its tenth part, which describes Krishna's childhood and youth spent with ardent lovers in Vrindavan. With this background, the paper finally focuses on Bengal Vaishnava texts and practices: to conceptualise flute acoustics as drawing the devotee and god in relations of both yogic sameness and aesthetic difference, that is, breath becoming flute sound, devotee becoming god, and/or the flute tunes attracting the devotee towards her divine other, outside of herself. Natya Sastra's/Bhagavat's aesthetics, and yogic/tantric worldviews, I argue, cohered in specific deployments of sonic theology, especially in notions of AUM sound and the nasal tone with which it fades-as being Krishna's flute sound, and bearing specific relations with the religiously cultivated body.

The Bhagavat Purana serves as Bengal Vaishnavism's discursive charter, itself influenced by yogic, tantric, and aesthetic developments. This syncretic discursive milieu, informing notions of an esoteric, yogic, yet devotionally aesthetic body, impacted Bengal Vaishnavism's rich textual heritage, including the 16th century productions: Bhaktirasamrita Sindhu, composed by the famous ascetic practitioner-theologian, Rupa Goswami, in Sanskrit, and Chaitanya's biography in Bengali, Chaitanya Charitamrita, by Krishnadas Kaviraj. I analyse significant tracts on the flute prominent in this textual oeuvre, to argue that flute metaphysics sensationally animates the Bengal Vaishnava theological paradigm of achintya-bhed-abhed (inconceivable sameness and difference) between the god-instrument, devotee-instrument, and devotee-god. This philosophical focus, I demonstrate, however, brings together centuries-long developments of ideas on the flute, and divine sound in general. I also analyse a few life narratives of makers and players of bamboo flutes in Bengal, some Vaishnavas themselves, understanding their oral lore about the flute's cosmic 
origins, and essential corporeal connections. Finally, I study religious imaginations of the flute in devotional song narratives dedicated to Radha-Krishna (kirtan), extremely popular in Bengal, which exemplify the textual interplay of monism and dualism between Krishna and his lovers, experienced especially through the deity's favourite accompaniment, the melodious bamboo flute.

We shall therefore see, for instance, that combining classical aesthetic idioms of divineromantic love, yogic/tantric philosophies, and Bhagavad Gita's description of Krishna himself as AUM's buzzing power (8: 9-13), flute sounds are described in Bengali oral lore as driving Radha (feminine energy at the body's base) to meet Krishna (cosmic male energy in cranial region), and becoming indistinguishable from his AUM breath, within the devotee's own body. I also bring together, for the first time, Natya Sastra's description of flutes as mostly having nine perforations (Abhinavabharati 5.1), Bhaktirasamritasindhu's description of Krishna's vamsika flute with nine pores (Southern quadrant, first wave, 368), Gita's description of the human body as nine-doored (5.13), ${ }^{3}$ flautist practitioners' explanations of the flute's 'transcendental note' (anarsvar) — the fifth one-which can be played only when all nine flute-holes are shut, ${ }^{4}$ and Bhagavatam and its popular vernacular renditions describing the nine-holed vamsika played by Krishna to generate the most enticing, sweetest-sounding fifth note to attract his lover-devotees in the quintessential passionate encounter in Vrindavan during the autumnal Rasa dance (Ghosh 2018, p. 411). ${ }^{5}$ Indeed, Bhagavat's aesthetic lover Krishna and Gita's yogi Krishna cohere in my analysis, since the fifth flute note is generated by shutting all nine vamsi-holes, which corresponds to the yogic practice of closing what Gita describes as nine bodily pores, and pulling breath-air inwards to resonate AUM, which blends into the finest bodily flute sound.

The body's yogic transformation thus aims at realising Krishna's flute hum within oneself, rising through body-chakras, attuned to, and harmonised with the breathing spacious cosmos both within and/or without. The question remains: is this flute played inside the body, or receives Krishna's breath and lip-nectar from outside; does the devotee realise her lover-god as indistinct from herself, or separate? The paper indeed tries to foreground a peculiar devotional aesthetics in which the devotee's body sings as the flute, to simultaneously become Krishna and remain discrete.

\section{Aesthetic Context of Outer Flute Sounds}

\subsection{Nada}

AUM sound has been identified as the first cosmic vibration in Vedic Hinduism, venerated as the sacred syllable par excellence, and identified with the greatest divine power, Sabda-Brahman. In later theistic traditions, and Tantras, Yoga, and musicological texts influenced by them, this acoustic energy is referred to as Nada-Brahman. Nada-Brahman gives life to both linguistic and non-linguistic sounds. It is an esoteric notion including both ahata nada (struck sound) manifesting in musical instruments, and anahata nada (unstruck, uncaused, primeval sound) revealing the same resonances in a meditator's inner body-mind, as discussed in yogic texts. The discursive tradition of sonic yogic practices, Nada-Yoga, thus establishes an inner corporeal soundscape of subtle acoustics, including instrument sounds, which are also replicated in the external world through making and playing musical instruments (Beck 2013, p. 145). Krishna's flute sound itself is termed nada in bhakti poetry (Beck 1995, p. 96), which can thus be sensed both internally and externally. Selina Thielemann refers to these two aural states—internal and external—as 'received' and 'offered' music, respectively (1999, pp. 333-34 cited in Beck 2013, p. 161).

How exactly the intuition of inner divine sounds translates to the external world of (making and playing) religious musical instruments is an intriguing matter, and flutes especially stand out in this regard, being the simplest yet most tuneful constructions.

\subsection{Flutes}

The classical Indian text of religious aesthetics, sage Bharata's Natya Sastra, was the first to discuss instruments and their worldly sound lives. Its twenty-eighth chapter is 
dedicated to four kinds of apparatuses: stringed (chordophones), covered/percussion (membranophones), hollow (aerophones), and solid (idiophones). Of these, flutes belong to the perforated or hollow (sushira), breath-dependent, aerophone variety (Pande 1996, p. 278). Thirteen verses in Natya Sastra are dedicated to these aerophones, and some further details are recorded in the 10th century CE Kashmiri Saivite saint-philosopher, Abhinavagupta's commentary on Natya Sastra, the Abhinavabharati. ${ }^{6}$

Flutes are mostly bamboo-reed cylindrical tubes, closed at one end, without any joints or knots, and with varied lengths. These hollow bamboo instruments allow air passage which excites resonators (Abhinavabharati 6.2-6.3). Longer flutes are deep sounding, and smaller ones, high-pitched. Some flautist families in rural Bengal still cultivate bamboo forests, to carve and sell flutes for a living.

The bamboo used to construct flutes must not be too old or young, thick or thin, not overtly shaken by wind, and dried for more than a year so that it has less weather-related fluctuations, before holes are bored in correct intervals on the flute pole, for mathematically precise pitch and scale. The exact numbers of holes are dependent on philosophical considerations (see below), music and religiosity being indistinguishable in Hindu sonic practices. However, Abhinavabharati 5.1 states that the flute mostly has nine holes: seven for the notes, a mouth hole (receiving and filling the pipe with breath) and an end hole (obstructing breath with a small plank) (see also Pande 1996, p. 284).

The normal human voice range of seven notes and two and a half octaves-deep first octave, smooth second, and sharp third - can be played on the essentially breath-dependent flute through various manoeuvrings of finger coverings and trembling, cross-fingerings, and mainly, manipulations of wind pressure-over- and under-blowing and air column vibrations (Krishnaswamy 1965, p. 60; Pande 1996, p. 284, Abhinavabharati 6.4). Texts mention the qualities of good blowing as steadiness, fullness, good intonation, etc., and bad blowing, conversely, as over-breathiness, under-breathiness, inflexibility, and unsteadiness (Sangitnarayana 2.125-6. See Bose 2009, p. 397).

The connection between the flute and human body are innate, both in classical aesthetic and yogic representations. Natya Sastra mentions that the flute's (venu's/vamsi's) main function was to follow vocal melodies in performance music dedicated to gods, accompanied by the veena, a sacred string instrument. Venu-veena thus served as the perfected form of sonic synchrony (Natya Sastra 30.9-11 cited in Pande 1996, p. 284, Abhinavabharati $2.2,6.5)$. However, the veena has explicitly been compared to the human body, since the body's vocal cord and breath rhythms attune it to the finest forms of acoustic vibrations such as hyper-tuned stringed instruments (Natya Sastra 28.12 cited in Bandopadhyay 1995, pp. 164-65). The venu-veena and body thus form an ideal harmonised expression of sonic potential.

There is also a vibrant Bengali oral lore about the flute's origin, which kirtan musicians narrated to me. The episode is also recounted in Brihat-Krishnalila-Saravali. Composed in the mid-19th century, it is a Bengali verse-form of Bhagavat Purana's tenth chapter. The text combines Bhagavatam's classical narrative with stories from other Puranas, and innumerable oral recollections transmitted over generations through oral songs, poems, folklore, and theatre (Ghosh 2018, p. 10). The narratives are memorised by communities listening to them during regular evening village sermons by gurus. According to the folklore, the flute was obtained during the first churning of the ocean by gods. A $24 \frac{1}{2}$-node bamboo pole was collected, and its various portions used for making gods' weapons, and one half internode constituted Krishna's flute. Musicians add that Krishna has three kinds of flutes, and the deity of speech and sound, Saraswati, resides in them, and obtains the passionate flavour of Krishna's kissing lips. This intimately associates sound, eros, and divinity. Bamboo, the text says, performed several austerities in previous births (during Rama's time), and thus despite being an unconscious, lifeless entity, gained life, agency, and the most coveted position on Krishna's lips, as his flute (Ghosh 2018, p. 200-3). ${ }^{7}$

Parallel to classical texts such as Natya Sastra and Abhinavabharati describing aesthetic potential as physical musical forms, were discursive developments in Yoga which spoke 
about Nada-Brahman constituting meditative inner worlds. I now turn to texts which describe the body as throbbing with anahata nada, the unstruck, uncaused aural field, which itself embodies in both the internal anahata breathing body-flute through its toned chakras, as well as ahata physical flutes, externally struck with human breath. In turning from the aesthetic world of outer gross sounds to the yogic world of subtle inner sounds, the question looms about whether when the body resonates the flute, that sound is conceptualised as arousing divine breath inside, or receiving it from god outside.

\section{Spiritual Context of Inner Flute Sounds}

\subsection{The Yogic Tradition}

The realisation of the body as flute germinates in notions of an incessant cosmic breath flow inside corporeal interiors. Yogis become aware of this vibrating interiority, and through practices of stilling breath flow, the body echoes AUM - cosmic breath and sacred sound gradually becoming indistinguishable-its nasal tone tapering as the flute's adenoidal melody. Further, since the flute is considered to be Krishna's essential symbol, attached to his bodily being, thus AUM is also indistinguishable from Krishna, the devoteeyogi's body interior thus becoming the flute-flautist Krishna. From a phenomenological perspective too, yogic practices result in breath becoming more lightweight, the inner soundscape simultaneously becoming subtler, higher meditative stages then resounding instruments such as the flute fused with whistling breath. These discursive thematics of yogic ontology may be distilled from a variety of texts with distinctively evident and insistent conceptual overlaps, compositions which although separated by centuries, institute analytical parity, with connections posited between bodily and sonic imaginations.

Kaushitaki Upanishad is a part of the Rig Veda, dated around 1st century CE. The first verse in its second chapter states that prana, or body's vital air or breath force, is ultimate divinity (Srimad 1992, p. 23). Prana is a sentient, conscious, sensing force, and thus in the famous Upanishadic tale of competition among sense organs about who is most crucial for life, prana emerges victorious. The one who is aware of prana's superiority attains gods' immortal nectar (amrita) (2: 14 cited in Srimad 1992, p. 37). Additionally, following Kaushitaki Upanishad, prana and vaak (sound/speech) are mirror reflections. Thus, it says that when one talks, breath/god transforms to speech, and in silence, speech submits to breath (2: 13 cited in ibid: 35). Therefore, the aware devotee-yogi realises one's own breathing/sounding capacity as divinity. When the divine flautist fills his breath into the flute therefore, it sounds an external melody, while when he retains speech/air and concentrates on inner breath/sound, the body reverberates the flute echo. While prana and vak are reflections, vak also represents life's fiery, feminine creative potential stemming from the inert, silent male energy (Gita 10: 34). Vaak's fire is kindled by breath-air, and the term pranaagni (breath-fire) thus also refers to life vitality (Gita 4: 24-38). Prana/vak, male/female thus reflect in the same corpus. These ideas of breath-sound-divinity correspondence resonate quite directly with Bhagavad Gita's theorisations.

Krishna declares in the Gita, that that he is akshara, the first syllable or cosmic vibration, indistinct from eventual divinity—the sonic energy known as AUM $(7: 8,13 ; 8: 9,10 ; 9$ : 17). Like silent breath stands behind all mortal activities as the vital overseer, Krishna is the witnessing self (9: 18). Krishna as a breath-air-sound force thus resides within the devotee's consciousness, and he becomes aware of this divinity when through Yoga he stills his prana in the middle of the eyebrows and concentrates fully on AUM resonance rising from within (8: 9-10,12-13). This AUM breath shining vibration is Krishna's yogaishwarya (yogic magnificence), knowable to any sincere meditator (11: 4, 8; 17: 75). Krishna calls this becoming madbhavam, full of my thought, and therefore, same as me (14: 19). We will later find the same sensibility echo in Krishna's lover-devotees' minds fusing completely with his flute sounds in the Bhagavatam. The devotee thus becomes Krishna by focusing on his own inner breath/sound potential. Gita asserts that such self-controlled embodied beings then reside contented and enraptured in the city of 'nine gates', that is their bodies (5: 13). The notion of the nine gates (navadvara), dvara literally meaning an opening, potently 
resonates with Natya Sastra's / Abhinavabharati's description of the flute (vamsi) as having nine orifices, the one Krishna blows on during Bhagavatam's Rasa dance. The yogic body and flute are thus similarly perforated, cosmic breath-air passing through their holes, and their porous body surfaces booming with sound, since both bodies/flutes are expressions of the same uncaused, unstruck divine sound energy (AUM/Krishna) residing within every conscious existence.

The pre-Christian Indian epic, Mahabharata, of which the Bhagavad Gita is a part, also refers to qualities (gunas) of akash or ether, the holder of cosmic sound, as ubiquity, unspeakableness, eternity, being unstruck, and presence in the body's perforations (chhidrata) (Shanti Parva 255: 7 cited in Sinha 1987, p. 793). The Mahabharata / Gita thus unswervingly pre-empts the understanding of body as flute. However, while Gita's yogic temperament unequivocally situates the divine with his flute within the meditative body, Bhagavatam has a more ambivalent monist-dualist temper, unable to strictly posit whether Krishna plays the body-flute from outside, or becomes the flautist inside.

The thought-structure of Kaushitaki Upanishad, Mahabharata, and Bhagavad Gita, about breath-sound relations as constituting the primal embodied vibration in a person's corporeal interiors, have intrinsic connections with notions of the throbbing AUM buzz analysed in Yoga Upanishads. The Maitri Upanishad (6.22) indeed says that practices of 'mystical audition' of Nada-Brahman have been especially emphasised in lineages of Yoga-Upanishads and Hatha-Yoga texts (Beck 1995, p. 92).

Hamsopanisad is the fifteenth among 108 Upanishads and one of 20 Yoga Upanishads. It discusses the involuntary nature of sacred breath and how it reveals divine knowledge. It says that cosmic vibration (AUM) constituting all existence, including the core of human bodies, is the result of divine male-female union. ${ }^{8}$ The male seed as Ham buzz and female energy as Sah echo, unite, and flow continuously as the hamsa sound inside the body, fused with automatic breath, which resounds 21,600 times spontaneously. This anahata nada, unstruck and uncaused, is referred to as the ajapa, unchanted, mantra. The yogi learns how to still the inspiration-expiration cycle in a middle resting point (kumbhak), and then reverse breath flow, such that, hamsa then resounds soham, literally meaning 'I am that', thus realising the self as divinity, or cosmic male-female energies united within (10-13 cited in Ayyangar 1938, pp. 492-98). This hamsa buzz is conceptualised and felt as AUM sound, and in the process of reversing breath-air and approaching soham (while uttering AUM, the $\mathrm{M}$ extending), ten different kinds of hums (nada) are heard in the meditator's right ear, rising from the inner body: cin, cini-cini, bell, conch, wire of harp, cymbals, sweet flute note, kettledrum, tabor, and roaring clouds (16 cited in ibid: 500). These sounds are associated with different bodily reactions. The seventh level or hearing the flute is concomitant with secret divine knowledge beginning to reveal itself. Sacred experience thus begins exactly with flute-echo, and gradually, the yogi embodies the turiya ('fourth') or Para-Brahman state (18-20 cited in ibid: 501).

The state of para or turiya is conceptualised as both the after in the sense of transcendence, and primal enabler of, the three syllables, A-U-M, and tantric speech-states: pasyanti (in the navel, corresponding to deep sleep), madhyama (chest, dreaming), and vaikhari (tongue, wakefulness). Turiya is approached literally through the nasal buzz after AUM's $\mathrm{M}$, represented as the symbol *, which gradually leads towards vacuous emptiness, or the divine ether which the meditator's consciousness merges with in the cranium. This dimension of the four states of sonic/consciousness development coincides with tantric ideas of how the essential feminine energy, the coiled serpentine power in the body's anal base, kundalini, rises along the spinal cord in an inverse direction, finally uniting with the male principle in the cranium. She is herself the essential AUM* sound (nada) whose fourth element, ${ }^{*}$, unites with turiya-Krishna, nada merging with prana (see Padoux 1992, pp. 20-22, 83-84, 130-31, 133, 143, 168, 172-88, 201). Hamsopanisad and tantric ideas taken together signal flute sound as the passionate merge of corporeal male-female energies, and the devotee-yogi becoming the divine. 
These aspects are further developed in Amrta-Nadopanisad, another Yoga Upanishad, the twenty-first among 108 Upanishads. Here too it is stated that following the practice of A-U-M utterance, the yogi should tread M's vowel-less echo path towards the subtle state without any syllables or vowels, the empty ether of Brahman-ness. It says further that AUM is the chariot which should eventually be abandoned at the end of the journey (2-3, 20 cited in Ayyangar 1938, pp. 9-10,13). This end of journey, achieved through breath-stilling (kumbhak), is the Para-Brahman state, when the yogi attains samadhi (transcendental union), becomes divine, 'same as that' or Soham (inverse of hamsa) $(7-8,16$ cited in ibid: 10, 12). In a tantric idiom, he realises his body as the site of cosmic male-female union, characterised by a distinct sonic hum. Interestingly, the Amrta-Nadopanisad mentions seven doors which lead to divinity or the fourth state, turiya. One of them is known as susira (26 cited in Ayyangar 1938, p. 14). It is instructive that the flute is characterised as a susira (perforated) instrument in Natya Sastra, and we can again conceptualise the body-flute, perforated with breath passages, and transforming to sacred sound, as the manifestation of ultimate divinity.

The equivalence of breath/AUM/hamsa sound, transforming to subtle sacred sounds including the flute hum, is most vividly described in the celebrated text, Nada Bindu Upanishad. ${ }^{9}$ It is the oldest and most significant text among Yoga Upanishads on the precise meditation of sound (nada) (Beck 1995, p. 93). AUM is here literally referred to as hamsa (white swan) bird, with three distinct parts: A-U-M, and a half-metre, ardha-matra, the nasal buzz after $\mathrm{M}$, which embodies the bird's most important head. This half-sound fades into the echo of Para-Brahman, the eternal light-sound. When through Yoga, and pulling up breath-air along the subtle spinal path, one glides into this state, he attains Brahma-hood, and his illusions of difference with the divine vanishes $(1,5 b-6 a 8,17,20$, 29b-30). Similar to the discursive thrust of other Yoga Upanishads, the text mentions that in the process, the yogi hears internal sounds in the right ear (31). He may choose to focus on any one of those sounds, and being concentratedly fixed on it, he gradually enters the turiya, transcendental state (32). Like in the Gita, the sonic absorption, like milk mixing with water, is understood as attaining the divine within the body $(38,41,42-43 a, 43 b-44 a)$. These sounds are typically heard as loud ones in the beginning, becoming more and more subtle (33) with time, practice, and correct yogic ascension of light breath through the body's spinal channel. Thus, lower meditative stages are associated with sounds of the ocean, clouds, kettledrum, cataracts, bell, horn, etc., and higher stages with delicate echoes of tinkling bells, veena, buzzing bees, and the flute (34-5). ${ }^{10}$

Thus, this text's characterisation of flute sound as a higher meditative state is similar to the Hamsopanisad. The flute's acoustic, represented as an advanced spiritual auditory experience in all Yoga texts, is directly related to its breath dependence, and its subtle nasality being indistinct from the adenoidal ' $\mathrm{M}$ ' of $\mathrm{AUM}$, which apprehends cosmic emptiness.

Nada Bindu Upanishad also suggests that one may shift concentration from gross external sounds to subtle internal ones, remaining strictly loyal however to that sense of sound (37). Thus, whether one is listening to the flute in a performative setting as described in the Natya Sastra, or relishing its ravishing attraction inside the body, flute sound remains the only conscious, sentient existence, fused with the yogi-listener, while he becomes oblivious of everything else (43b-44a). Paradoxically, this sound is referred to as Vishnu's seat (46b-47a), while the text also talks about transcending all sounds to move towards a soundless state (ashabda) (49a) which is Para-Brahman (47b-48a), the indestructible akshara, attaining which the yogi no longer hears any sound (52b). Further, the yogi himself then becomes of the 'form of the internal sound', AUM. In this most subtle reading then, AUM is no longer conceptualised as sound, but as merging into ether vibration, imagined as soundless. There is thus a productive ambivalence between ultimate divinity as sound (Nada-Brahman) and soundlessness (ashabda), in Nada Bindu Upanishad. Following the first strand of imagination, Krishna plays the flute inside the body, and in the second, goes beyond any physicality, towards emptiness. 


\subsection{The Yogic-Tantric Anatomy}

The 15th century text Hathayoga Pradipika is considered seminal for Yoga practitioners. Its auditory system utilises the discursive framework of Yoga Upanishads, while also integrating parallel tantric developments. I shall briefly summarise some tantric ideas of sonic metaphysics, much overlapping with the yogic physiology described above. Supreme divinity (Para Brahman) is conceptualised as the union of the male principle (purush) Shiva's seminal representation as a dot, bindu, seated in the cranium - with the feminine energy, prakriti, residing in the body's base. Their fusion, Nada-Brahman, is the first vibration, AUM, followed by ", which buzzes into the cosmos with a nasal droning hum (nada). AUM ${ }^{*}$ thus signifies the combination of male Ham and female Sah, which together flow in the body's right and left sides incessantly, and when through yogic methods, breath flow is reversed, it sounds soham, the body then becoming god (Omkarnathdev 1990, pp. 16-19). When the otherwise sleeping feminine life-energy in the anal region, excited by the practitioner's continuous utterance of AUM, feels restless to unite with her male counterpart and reverses her flow upward, she embodies the same cosmic maleness in her being (pungsvarupini) (ibid: 35). During her journey upward, a number of sounds rebound in the body, as transformations of AUM, and stop in an empty sense of ether when she absorbs fully in the male, the fourth state beyond A-U-M (ibid: 44-45). These sounds are progressively felt as subtler, and embody for instance, cini-cincini buzzes, bells, conch, veena, percussions, roaring clouds, bees, and the flute (Omkarnathdev 1990, p. 56). Among these, venu-nada or flute sound is understood as revealing esoteric knowledge (ibid: 126).

Similarly, Hathayoga Pradipika explains that physical senses are controlled by the mind, the mind by prana or vital breath, and prana further dissolved in void through yogic precision, marking perfect stillness. The body then experiences anahata nada, or flow of AUM, which also transforms to other sacred sounds (4:29-30 cited in Muktibodhananda 1993, p. 510). Mind and prana become still through the breath's reverse flow to the cranium, which holds the male principle (bindu). Following the yogic-tantric anatomy, the text says that bindu is seated at the head's top back section (sahasrara chakra), and when breath is stilled there, kundalini, or the serpentine feminine energy, is deprived of life-energy, and she hisses and rises angrily, impatiently travelling in the converse direction along the chakras towards the male, and when united with him, nectar-like nada is produced, which flows down to the middle of the eyebrows (ajna chakra) and booms throughout the subtle body (4: 28 cited in ibid: 508 ).

The yogi desperately aspires to experience these inner sounds, and his search (nadaaanusandhan) rests when he completely absorbs in those acoustics (65 cited in Muktibodhananda 1993, p. 556). The tantric grammarian conception of four levels of emanation of speech/word (through the anus or para state corresponding to still vibration of malefemale union, where creation has not commenced; pashyanti, navel, where although the first sense of material differentiation has not yet begun, it may just be apprehended; madhyama, chest, where differential concept formation about matter takes place, and vaikhari, mouth from where gross speech springs) is relevant here (Padoux 1992, pp. 20-22, 8384, 172-88). Following Hathayoga Pradipika's explanations, hearing a physical flute corresponds to: vaikhari/wakefulness state, the subtle ability to hear distant flute sounds: madhyama/dreaming state, hearing the flute when none else does: pashyanti/deep sleep state, and hearing the flute in transcendental states (para). The yogi's aim is to gradually subsume oneself in increasingly subtle audition states, from the struck towards the unstruck sound-vibration, vaikhari to para, immanent to transcendental flute hum (Muktibodhananda 1993, pp. 556-59).

The transition between the third and fourth audition states is the most intimate, esoteric, and absolutely crucial (also for our understanding of Bengal Vaishnava achintyabhed-abhed philosophy). The pashyanti stage corresponds to hearing Krishna playing his flute inside the body itself, and none but the self then perceives it. Similarly, Iyer (1977) describes the best music hearer as one who does not remain separate from the music, and to characterise this 'ceaseless utterance in eternity', he refers to flute sounds as the most 
refined spiritual knowledge, the subtle echo in which all material sounds resolve. The para stage, however, refers to a transcendental beyond (expressed simply as, nothing but, Krishna playing his flute), which may be intuited during the bodily sense of complete stillness, but may equally imply Krishna's being outside the physical corpus altogether, blowing on his flute independent of being heard. In this understanding, both pashyanti and para are about soundful states, with/without being perceived. This reading also comes closest to para being imagined as soundlessness in Nada Bindu Upanishad, since when sound is unheard, it may be conceived as soundless or silent, though it is still definitely vibrational.

In the state when the male-female, consciousness-energy principles unite in the yogi's body, he sits with this eyes, ears, nose, and mouth shut, and hears distinct sounds at the back of the head and inner right ear. As the six chakras (anus, genital, navel, chest, throat, middle of eyebrows) are gradually pierced with the yogi uttering AUM, inner sounds reverberate and become subtler from being loud and voluminous (4: 67-68, 84, 86 cited in Muktibodhananda 1993, pp. 561-63, 578, 581-83). In the arambhaavastha, anus void, the unstruck sound assumes tinkling sensations, represented as transcendental Krishna playing his flute. In the ghataavastha, chest-chakra, the kettledrum is heard, in parichayaavastha, throatchakra, drum, and in nishpattiavastha, eyebrow-chakra, breath approaches divinity, and again the veena or flute echoes. Hearing the flute at this level of subtlest breath retention is associated with nirvikalpa samadhi or becoming one with god (4: 70, 73, 74, 76 cited in ibid: 567-74).

Flute sounds thus characterise the two most significant perforation points of the yogictantric anatomy which approach transcendental states: the anus and the middle of the eyebrows. The first awakens and arouses kundalini upward towards her lover, and the second vibrates when the lovers unite. The devotee-body thus becomes indistinct from Krishna playing the flute. Once again however, such as in the earlier Yoga Upanishadic tradition, there is the nuanced inside-outside dialectic in the closing verses. Thus, Hathayoga Pradipika says that when the mind merges with anahata nada or flute sound, it embodies Vishnu-hood, that is, the devotee becomes divine (4: 100). It then suggests however, that anahata nada ultimately gives way to soundlessness, all feminine energy/vibration fusing with the still cosmic formless purusha (4: 101-2. See Muktibodhananda 1993, pp. 587-88).

This dialectic, I argue, is resolved in the understanding of the transcendental state as Krishna playing/vibrating the body-flute, irrespective of being heard/realised. While yogic discourses of sound are thus overwhelmingly monist, situating the divine with his flute inside the body, debating however about whether or not that sound is the ultimate or gives way to soundlessness, the Hathayoga Pradipika, in my reading, opens up complex possibilities. Here, the para state is about transcendental Krishna-with-his-flute. When realised by the yogi, his body-flute sounds, and he becomes aware of Krishna as present within himself, as also an independent transcendental existence. When not fully realised, however, para remains akin to soundlessness, though vibrational still. However, the potential always remains in this fourth state, to be sensed and embodied by the yogic body. Krishna is thus also potentially outside the devotee-yogi's body, a separate force in himself. These subtleties in yogic thought pre-empt Bengal Vaishnavism's position about understanding the divine flautist as situated both in/outside the physical self.

\section{Flautists' Narratives}

Flautists' life-narratives and everyday instrument experiences resonate with senses of yogic solitude, and cultivated relationships with their bodies, as detailed in texts of religious sound. Therefore, I went searching for a flute-maker, but found a flautist in the truest sense, in Anil Mitra: who loves, lives off, and lives for the flutes he makes and plays. He stays alone in a quiet suburban Bengali neighbourhood. He was always fascinated by the call of flute sound and left his home as an adolescent since he did not want a usual life with a job and family; he could not however afford to pay flute-gurus, and thus learnt the instrument on his own through attentive listening. He brings bamboo poles from Assam 
and carves flutes of varying sizes. After talking about the nuances of making flutes, he chose to explain playing methods not by talking, but blowing variedly on the mouth-hole, accompanied by deft movement of fingers. With no tune in one's vocal cord at all, he explained that one may still be an ace flautist through carefully cultivated intuitions of the amounts of breath to be blown, and finger-manoeuvering. It is bamboo's and the bodymind's materialities together, which render the flute's melody, he softly demonstrated. Bamboo's lightweight and porous texture allow breath's relaxed spontaneity to craftily escape through its pores, and the body's interior should be equally cleansed of cough, etc., and breath's swift movement ascertained through yogic breathing exercises (pranayama), along with clarity in tonal intuition. Anil prefers to stay indoors all day, and said that his perfect companion is the flute, merged with his body, breath, and focused mind.

Subir Ray, with a Master's degree in music, is a more accomplished flautist, prominent in Bengal's radio and TV shows, film background scores, and solo stage performances. $\mathrm{He}$ is also a flute-collector, and has over a hundred varieties from over the world. His effortless phenomenological blending of Yoga and flute affect is significant. He explained that most meditation music is flute-based since its sounds come closest to silent breath. He started Yoga practice in early adolescence, and has read voraciously on pranayama techniques. He says that his physical senses have generally altered: he does not feel too hot or cold, can sit in one place practising the flute for more than twelve hours, and his mind has become as 'pinpointed as an arrow', through sustained pranayama regimens. In playing the flute, the precise calculation of breath-and-finger-manoeuvering 'opens up the chakras' and realises consciousness (bodh) he said. He described bodh as possessing subtle breath-like (dom) qualities of expansiveness, clarity, and flexibility of traveling to and sensitising different body parts. Unlike other instruments, he explained that unless a note is achieved in the mind, it cannot be blown accurately in the flute, and thus more than the health of lungs, lips, jaws, teeth, wrist, and nerves, the mind's meditative state is most crucial. Resonating with the tantric notion of fourfold speech emanation, Subir said that he plays the low octave (udara) by pulling breath from the navel, middle (mudara) from the chest, and high (tara) from the throat, and thus the air-passage needs to be clear and swift in the body-interior.

Both Anil and Subir emphasised that the celebrated note in Krishna-aesthetics, the fifth one, sounds strikingly beautiful, and is played by shutting all holes with fingers. Subir said that it is an anar svar (transcendental note), which never changes, with reference to which other notes are adjusted, and which impacts listeners with an unfailing sweetness, just as pulling breath up while closing all body-pores generates sensitive quivers in the yogic body.

Like Anil, Subir stays cooped up in his flute studio all day, dedicating his fullest attention to tying the insides of his breath with the flute's. He said, 'Through years of continuous practice and body-mind concentration, I realise that my body is a flute, singing inside, and so when I stop playing the flute at the end of the day, my breath keeps the melody through the night'.

However, Subir's narrative takes most nuanced ambivalent turns, when he says that although the flute relationship for him is perfectly yogic, situated within his body-breath, since the age of 22, it also generated in him intense bhakti for a definite god. This Yogadevotion ambiguity is ultimately about situating god within oneself, and also outside as a separately identifiable force. These popular flautist narratives have strong reverberations with inherited textual traditions of Bengal.

\section{Towards the Inside-Outside Dialectic}

The dialectic of becoming the divine and remaining distinct, the flute being blown from inside or outside the body, is rooted in understandings of the transition from Vedic ShabdaBrahman to yogic, theistic Nada-Brahman. In the yogic-tantric Nada-Brahman traditions, the feminine merges with the male, nada with bindu, half-moon with the dot, the ultimate

$*$ taking its position above the tripartite ontological expression of life: A-U-M. While in 
monist Vedanta, the fourth (turiya) position after A-U-M is considered a formless, static, ashabda (soundlessness) or amatra (with no temporal extension, and thus no sound) state, the nasality of ", the half-syllable, ardha-matra, rather takes on an embodied divine form in Yoga, representing for instance, Krishna blowing on his flute. The nasal sound embodies the combination of stillness (purusha) and vibration (prakriti), Yoga and devotion (Beck 1995, pp. 81-91). It generates a very subtle mediation between the fourth state understood as sounding and soundless. I interpreted this through Hathayoga Pradipika's understanding of transcendental sound, or Krishna-with-his-flute, as the fourth ontological, vibrational state of existence, with (soundfulness) or without (soundlessness) being physically or subtly perceived. However, the idea of Nada-Brahman thus completely fuses with the Upanishadic conception of AUM, and through fine tantric developments, situates itself also in the body's chakras (energy stations) and levels of speech manifestation (ibid: 97).

In a distinct tantric reading, feminine energy (Shakti) is understood as explicit, creative, the male (Shiva) as implicit, static, formless; and their union, sound vibration, the unstruck Nada-Brahman, as Vishnu himself (Omkarnathdev 1990, p. 28). Vishnu/Krishna is thus perfected vibration, the flute sticking to his lower lip humming as idealised sacred sound. Like in the Gita, Krishna discloses himself as a sacred sound vibration in Bhagavat Purana too, a tremor, like fire resulting from the friction of wood (11.12. 18 cited in Beck 1995, p. 185). The $900 \mathrm{AD}$ text, Bhagavat Purana, composed in the devotional setting of South India, integrates aesthetic theories of Natya Sastra, and devotional philosophical modes, with Upanishadic, yogic, and tantric conceptualisations, including about levels of the body's mystic plexuses (ibid: 183-4). Thus, the idea of the tantric emanation of word is also subsumed in Krishna manifesting as Nada-Brahman, within the acoustic human body, transforming vital breath, prana, into subtle nada. Krishna thus claims to arise as the fourfold sound energy through the anus (para), navel (pashyanti), chest (madhyama), and throat (vaikhari) (Bhagavat 11. 12.17 cited in Beck 1995, p. 186). Bhagavata asserts, therefore, that Krishna can be perceived as esoteric sound within the worshipper's body (11.27.23-24 cited in ibid: 186-7). He is the fourth beyond A-U-M, and meditating on this form as bhagavan, the devotee directly attains Krishna (11.15.16 cited in ibid: 187). As discussed before, this yogic Nada-Brahman is therefore the Krishna-flute's nasal sound. Reminding of the perforated body mentioned in Gita, the Mahabharata also adds that this hamsa/AUM form of divine sound as Krishna's flute, flows within the nine-doored human body (Shanti Parva, 239), alerting again to Krishna' vamsi with nine pores/doors. Simply, Krishna's own breath, $\mathrm{AUM}^{*}$, congeals as ${ }^{*}$, the flute hum, and flows through yogic bodies' nine pores as primordial sound. These bodies themselves become Krishna's beloved flute.

Bengal Vaishnavism utilises the entire discursive corpus of Yoga, Tantra, devotion, Upanishads, Gita, and most heavily, Bhagavat Purana. Beck indicates that the idea of NadaBrahman impacted Bengal Vaishnava works like the 15th century Sangit Damodara, and 18th century Bhakti Ratnakara (5.2505-6) (Beck 1995, p. 109; Beck 2013, pp. 174-77). The critical 16th century Bengal Vaishnava ritual text, Haribhaktivilasa, states that tantric knowledge is most significant for the sect. The tantric seed-syllable for Krishna, for instance, is klim, and Radha, hrim. Dimock further explains that there are five letters in Krishna's seed: Ka, La, I, M, followed by the sign of nasalisation (1966: 82 cited in Beck 1995, p. 198), solidifying as the sound of Krishna's flute.

Nada-Brahman is about divinity as definitely sonic, and this yogic temperament is actively embraced by Bengal Vaishnavism, which does not subscribe to understandings of the sacred as abstract/empty//ashabda. However, unlike Yoga's unequivocal emphasis on the divine as absolutely located within the body, Bengal Vaishnavas, influenced both by monist Vedantic thought and the ecstatic devotion of rasa (aesthetic) theory, display a refined ambiguity about whether god is within, or outside (such as in the suggestive readings of Hathayoga Pradipika) (Gupta 2007). They maintain difference between divinity and humanity, and the importance of an emotional being with a spiritually refined body with which to worship god. Their ritual and affective corpus is thus also dedicated to Krishna as a discretely distinguishable external god, with identifiable affective qualities. 
The complex narrative of the devotees' sameness yet difference from Krishna/flute, the flute being played inside and outside the body, is palpably evident in the sect's dense analyses. This is fitting of its theological tenet, achintya-bhed-abhed, or inconceivability between union and separation, monism and dualism (Brahmachari 1994; Dimock 1963).

I shall now analyse several tracts dedicated to Krishna's flute in Bengal Vaishnava texts. Their narrative densities enrich the ambivalence between Yoga and devotion: the devotee feeling separated from both the flute and Krishna, becoming one with the flute and remaining distinct from Krishna, one with Krishna and his flute, one with Krishna, and then sounding the flute, etc. Additionally significant are implicit yogic understandings of the numbers of holes in Krishna's flutes, and esoteric experiences of its nasality. This involves the * of AUM, fusing in and as Krishna's flute sound, as also his nasal voice. Further, the nasal flute tone is said to especially manifest in the fifth note, celebrated as particularly melodious, and passionately and irresistibly pulling his devotee-lovers' hearts.

This fifth-note metaphysics draws together aesthetic, devotional, and yogic paradigms. Thus, Natya Sastra places the erotic experience as foremost among eight aesthetic emotional responses, and explicitly ties it to the fifth note $(p a)$ of the musical octave $(6.15,39-45$ and $19.38-40$ cited in Beck 2013, p. 149). Again, the fifth flute note is played by shutting all pores with the fingers, while blowing on the mouth-hole. This shutting of the nine-hole flute is the yogic/tantric counterpart of closing nine body pores while pulling breath up and sounding $\mathrm{AUM}^{*}$, its echoing fading tone, the body's nasal drone, ", then becoming Krishna's flute hum, the body becoming flute and yogi becoming Krishna, or the sound-perfected Krishnadevotee receiving his deep breath. What therefore remains the quintessential symbol of passionate devotion-devotee-lovers responding with their entire bodies to Krishna's fifth note flute call in Vrindavan's autumn bowers-also apprehends the most significant yogic practice of realising sacrality within.

\section{The Flute-Devotee-God Complex in Bengal Vaishnavism}

When Krishna shuts all pores of the simple lightweight bamboo vessel, completely empty inside, it sounds the nasal pancham (fifth) note, madly attracting his lovers. The sound is able to entice at all, however, because there is the same sonic mirroring potential in the listener. The body then desires complete absorption in the aural divinity, possible only in becoming the flute. In yogic terms, this implies emptying the devotee-self's ego, closing all bodily pores in a meditative gesture: shutting eyes, ears, nostrils, mouth, and then pulling up the rectum, genital, and other chakras, upwards along with life-breath. In tantric terms, expressed in a Vaishnava aesthetic idiom, the feminine devotee-self (anuschakra/kundalini/Radha) rises upwards towards Krishna (cranium), all along, the bodyflute sounding the fifth note.

Such yogic-tantric-devotional symbolic weavings are evident in Bengal Vaishnavism's textual corpus (both classical and popular), with ample ambiguities of achintya-bhedabhed between devotee-flute, flute-god, and devotee-god. Yoga deliberations about the monism/dualism debate, or whether the transcendental para state is inside or outside the body, often take on simple narrative forms in Bengal Vaishnava aesthetics-influenced texts, where oneness and difference are understood as either union with Krishna or feeling intensely separated from him.

Natya Sastra enlisted eight affects generated by the seven musical notes, the fifth one denoting refined erotic sentiment (sringara), most valued by Bengal Vaishnavas as the desired relational ethic between the devotee and Krishna. Such intense passion has two aspects: union (sambhoga) and separation (vipralambha), and both are potentially experienced through flute sounds. Abhinavagupta added a ninth rasa (cultivated affect): santa or peaceful, as culminating all others. The formless impersonal god this rasa approximates is analogous to an empty, abstract divine. But for the intensely affective community of Bengal Vaishnavas, sringara remains the exalted essence of devotion (Beck 2013, pp. 151-52). I argue however, that sringara itself-with dimensions of both union (sameness) and separa- 
tion (difference)—embodies peculiar articulations of Yoga and bhakti, monism and dualism, abstraction and aesthetics.

Krishna played the enchanting fifth note (murali-nada-mohitam) during his Rasa dance with gopis (women lovers), from which, Vaishnava music specialists imagine, all harmony notations were born (Bhakti-Ratnakara 5.2738 cited in Beck 2013, p. 176). This notion of the all-containing transcendental fifth note is congruent with the yogic understanding of all speech, sounds, and mantras being created from AUM (=flute nada). I argue, therefore, that the sonic aesthetic of Bengal Vaishnavism, centering on the idea of Nada-Brahman, is both thoroughly yogic and devotional.

I shall now discuss Bengal Vaishnava flute metaphysics drawing from Bhagavata Purana's aesthetic theology, which was shadowed by centuries of developments in Yoga, Tantra, and devotion, coming together in 16th century's Bengal Vaishnava discursive productions of Bhaktirasamrita Sindhu, Chaitanya Charitamrita, and also popular musical performances such as Bongshi Shikkha (flute learning), and other oral lore and narratives. Taken together, they animate the basic philosophy that devotees are and are not, the same as, and different from, Krishna/flute.

\subsection{Bhagavatam: Venu Gita}

Venu Gita (Song of the Venu), chapter 21 of Bhagavatam's tenth part (Saraswati 1975, pp. 306-17; Schweig 2005, pp. 78-85), ${ }^{11}$ describes the passions churned in nature-women, trees, birds, cows, clouds, bees, rivers, deer, peacocks, hills—on hearing Krishna's flute. Significantly, the women have not yet met Krishna; their romance has been kindled simply by hearing his flute's nada. Vrindavan's forests are filled with an autumnal breeze mixed with lotus smell, the perfect milieu to generate dalliance, when Krishna enters the bowers, vibrating his flute with his warm breath. The women, enraptured by the sounds, then begin discussing the flute-player, and some become still in silence (10.21.1-4). Breath and sonic potential, as discussed in the Upanishadic tradition, are fused, and thus breathing engenders both devotees' verbal speech, as also interiorised meditation, as equivalent states of Krishna-absorption.

Krishna fills the flute pores with the loving nectar of his lower lip, and the women embrace one another (21.5-6). Such communal ecstasy is a yogic unison: all bodies sensing the same meditative attraction to the deity-lover's phonics. The trees whose bamboo are used to make the flute relish the pride of their creation, and the rivers on whose banks they stand spring flowers like goose bumps on stimulated skin; peacocks think of the flute resonance as roaring clouds of passion and start dancing; the deer are maddened; wives of demigods lustfully aroused; calves with milk-moist mouths soak Krishna's flute sounds with their teary eyes, ears, and hearts; birds sit still on branches with shut eyes, unattached to everything else but the sweet flute vibrations; rivers desire him, creating excited whirlpools, and then thoughtfully direct their waves towards and embrace Krishna's feet, and clouds make an umbrella of droplet-filled shade for him to continue playing the flute in comfort, etc. (21.9-18). The text literally compares the birds' meditative, detached silence to sages' concentrated focus on Krishna's breath/sound (21.14), and while the waves' swirls personify vibrations of their intense sense of poignant separation from Krishna, their eventual united flow towards his feet signifies a monist temperament of divine merging (21.15). These whipping whirlpools are thus directly comparable to devotees' ambivalent feelings of differentiation and attentive union, together defining aesthetic desire.

In the most suggestive gesture, the gopis lament that the flute enjoys those most intimate pleasures (of kissing Krishna's lips)-leaving only leftovers as flute's sound for them-while they actually deserve the erotic nectar to the fullest. ${ }^{12}$ This clearly expresses gopis' envy at feeling separated from Krishna, and at sensing the flute's indistinction from his body. They infer that the flute must have performed severe austerities to earn this position (21.9). This indicates their desire and ability to embody a future path of meditative rigours to impress Krishna, and become one with his flute, and thus him. 
The Venu Gita is thus replete with expressions of monist absorption (abhed): being irresistibly pulled towards Krishna, cultivating silence, sage-like attention, unified devotion, concentrated listening, etc., as also painful separateness (bhed). The text thus says that the flute's tunes both stun living forms of life and cause non-living things to quiver in joyous passion (21.19). This dialectic of stillness in ecstasy and ecstasy in stillness ripples with the same affect as bamboo trees' feelings of simultaneous sameness and difference from the flute, as also the rivers' goosebumps-since goosebumps manifest in between the inside and outside of the skin surface. All these descriptions attest to the same phenomenon of indiscernibility (achintya) between identity and distinction of the devotee and flute, devotee and Krishna, prototypical of Bengal Vaishnava thought. Such achintya-bhed-abhed about whether the devotee-lover feels fused with Krishna through his flute sound, or the flute hum intensifies her passionate pain of separateness, I argue, together define the emotion of tat-mayatam (21.20), or the devotees' becoming completely full of Krishna, and identifying with him through ecstatic meditation. Being Krishna-absorbed can mean either total fusion with him, therefore, or focused senses of passionate difference; both stimulated by flute callings.

\subsection{Bhagavatam: Gopi Gita}

The same spirit of achintya-bhed-abhed is also deducible ten chapters later, in Gopi Gita (Gopis' song) (Saraswati 1975, pp. 430-41; Schweig 2005, pp. 51-7). ${ }^{13}$ This chapter is part of Bhagavat's Rasa-Panchadhyayi, five chapters dedicated to describing Krishna's most passionate encounter and dance with gopis in the autumnal Vrindavan forests (Rasa-lila), where he invited them with his flute echoes. At the heart of this episode, Krishna suddenly disappears, leaving his lovers in excruciating agony. It is then that gopis sing to remember him. In the final chapter of Ras-Panchadhyayi however, Krishna returns, and devotees ultimately realise that none can own him egotistically: he is the universal god, although individually and passionately knowable by all.

While in Venu Gita only Krishna's flute sound attracted his lovers, here their sense of separation and distance from Krishna is much more intense, since they have already tasted his romance. The gopis, missing Krishna deeply, sit together to discuss him, and so penetrating is their feeling of absorption that they enact Krishna's deeds, embodying the perfect monist temperament of becoming the divine lover (Soham: I am he). They opine that Krishna destroys vices such as lust and ego in his devotees, who realise that they are essentially empty, while he is their witnessing, indwelling self, antaratma (10.31.4-7). Later, the text compares this devotional realisation with a yogi's body overcome by bliss (10.32.8). In Bengal's popular musical performances (kirtan), this narrative is interpreted as devotees' bodies becoming flutes, by 'emptying' the bamboo pole and sounding Krishna's nasal flute tone in the breath-insides. The 'witnessing self' also reminds of Vishnu's yogic fourth state after A-U-M, or waking-dreaming-sleeping existences, within cultivated sonic bodies.

In Gopi Gita, the lovers desperately crave Krishna's lip-nectar, which is manifest in his sweet voice, healing words, and of course, piercing flute echoes (31.8-9). They complain to Krishna that, dragged by his loud flute melody, the enticing fifth nasal note, they have left behind their homes, husbands, children, and ancestors in the middle of the night, only to unite with him, while being the notorious indifferent flirt, he has abandoned them (31.16). They demand that he returns to them his lip-love which augments pleasures of union, dispels anguish, and makes devotees forget material desires. They lament further that all this is kissed away by the fortunate flute vibrating with his breath (31.14). While this emotion expresses the same jealousy as felt in Venu Gita, the desire to absorb Krishna's words, voice, and flute sound equally further indicates the equivalence of knowledge and affect, embodied by his flute. This reminds of the yogic idea that all aural expressions derive from AUM, concentrating in the flute's nasal tone. ${ }^{14}$

Devotional-aesthetic and yogic complexes thus cohere in Venu Gita and Gopi Gita.

The gopis envy the flute, wishing to understand the kind of asceticism it practices to deserve Krishna's affection; from that envy arises the desire to become the flute; such 
becoming involves yogic processes of emptying the ego, and realising the pored breathing body as Krishna's whistling flute. Krishna plays the flute's fifth note in Rasa, and Vaishnava devotees explained to me that his women lovers travel to meet him with their subtle bodies (sukshma sharir), and god dances with their eternal souls (Schweig 2005, p. 65). Since the fifth note is played by shutting all flute pores, this implies closing off all body-holes, senses, vices, and then breath travelling up the corporeal subtle path, pulling up chakras towards Krishna, while the body-flute's mouth-hole receives his divine breath. This yogic sensibility is perfectly expressed in Bhagavatam's description of gopis' Rasa dance as Krishna's dalliance with his own reflections (10.33.17).

We shall analyse further that there are different discursive possibilities of the flutegod-devotee relation: the flute resonates till devotees unite with Krishna, devotees embody the flute, the body-as-flute unites with Krishna and keeps buzzing, the body merges with Krishna and his flute, or the body unites with Krishna through complete absorption in flute sounds, and further, vibrates in ecstatic breath-flute reverberation when united with him. Following earlier debates in Yoga/Tantra, the final stage of Krishna Yoga or Krishna-love in Bengal Vaishnavism is thus not ashabda or soundless, but rather the fourth state of Nada-Brahman's nasal buzz, where the flute sound flows incessantly. Flute sound as NadaBrahman thus hums both when the devotee and Krishna are separate (bhed), and united in the same body (abhed) as prakriti-purush, kundalini-Krishna. Thus, the theological meaning discussed in kirtans about Gopi Gita says that the Rasa dance is about subtle individual souls (jivatma) uniting with their ultimate divinity (paramatma), gopis while enjoying Krishna, also realising that they are Krishna, kundalini-energy then completely identified with the fourth, turiya, transcendental divine. However, they also remain distinct from Krishna, to be able to taste and understand him.

\subsection{Bhaktirasamrita Sindhu}

The Chaitanyite sect, Bengal Vaishnavism, consolidated in a milieu when Indian aesthetic theory, and Yoga-Tantra with their distinct body-geography, were already developed, and its devotional ethics integrated these currents. Its chief theologian, Rupa Goswami, composed the magnum opus of bhakti emotional-religious aesthetics, Bhaktirasamrita Sindhu. Its tracts on Krishna's flute are influenced by the affective excess of Bhagavat Purana, aesthetic descriptions of Natya Sastra, as well as esotericism of yogic/tantric influence. In its Southern Quadrant, first wave, Krishna's characteristics and possessions which act as excitants for lover-devotees are discussed, and nine verses dedicated to his flutes.

Krishna's flute sound is described as able to penetrate saints' meditative trances, and containing all esoteric knowledge. The flutes are of three kinds: venu, murali, and vamsika. The venu is twelve fingers long, with thumb-thickness, and six holes; the murali has a pleasing sound, is of two hands length, with five holes including the blowing-pore; vamsika has nine holes including the mouth-pore, and is seventeen fingers long. Depending on the distance between the mouth-hole and first note-anything between ten and fourteen fingers - the flutes are known as Mahananda (most joyous) or Sammohani (enchanter), made of jewels, the golden Akarshani (attractor), and bamboo-based Anandani (blissful), especially dear to cowherds (364-72 cited in Haberman 2003, p. 217).

Experienced kirtan musicians, including vocalists, percussionists, and flautists cited these verses amply in my conversations with them, and unequivocally laid emphasis on the esoteric connotations of flutes' numbers of holes. Thus, venu's six holes correspond to the body's chakras (anus, genitalia, navel, chest, throat, middle of eyebrows); murali's five to the body's knowledge-acquiring sensory organs (jnanendriya): eyes, ears, nose, mouth, skin pores; and vamsika's nine to Bhagavad Gita's / Mahabharata's famous nine-doors (navadvara) or corporeal pores: eyes, ears, nose, mouth, genitalia, anus. In every sense, the flute thus becomes the body's mirror. The devotee wishing to imbibe, understand, and become one with divine breath needs to first empty oneself of vices and ego. Some practitioners, such as Subir Ray, thus explained that the venu's six holes also correspond to the six human vices (ripus): lust, anger, greed, attachment, ego, and envy, which must be emptied for devotional 
perfection. They should be burned with yogic asceticism, as holes are literally grafted onto a flute's bamboo pole with sweltering iron rods, he said. The devote yogi must then shut all bodily pores and pull up vital life-breath (prana), and with it, all chakras, focusing their sensory abilities on Krishna alone. Then, the inner breath-air fuses with anahata, the unstruck, uncaused whirling AUM sound inside, which merges in the middle of the eyebrows as the nasal drone, ${ }^{\circ}$, and the body booms with its flute hum, the yet-unheard anahata nada transforming into bongshi dhvoni (flute sound).

Such body-flute mirroring ties the two cultivated vessels as a single entity, fused as Krishna-lovers, objects of his passionate affection, becoming one with his breath-sound. Thus, in an instructive verse of the Southern Quadrant's second wave, Bhaktirasamrita Sindhu says that Krishna's blowing on the flute causes a whirlwind of moist, warm breath inside the instrument, as also inside devotees' heart-ears, who spin around in ecstatic anguish (19, cited in Haberman 2003, p. 239). This exact affective reflection is possible since the devotees' breath and flute's sound are congruous in the yogic body; in other words, the body is the flute, receiving divine breath. In the typical Bengal Vaishnava spirit, however, it remains ambiguous whether the body-flute is indistinct (abhed) or separate (bhed) from Krishna; whether Krishna is inside or outside the devotee. ${ }^{15}$

\subsection{Bongshi Shikkha}

Bengal Vaishnava oral musical traditions have internalised the textual-philosophical discourses, and a very popular kirtan form is Bongshi Shikkha, or Krishna teaching Radha how to play the flute. It craftily infuses the aesthetic-yogic theology of Bhagavata Purana's Venu Gita and Gopi Gita, and Bhaktirasamrita Sindhu's notions of the variously pored flute(s). I shall summarise the chief narrative structure of Bongshi Shikkha. ${ }^{16}$

Every Radha-Krishna kirtan-story is preceded by a corresponding episode from Chaitanya's life, since the saint is believed to be the divine form of Radha and Krishna savouring aesthetic sexual delight within the same body (Stewart 2010). Thus, a typical performance of Bongshi Shikkha begins with Chaitanya making the fifth flute note's sound with his mouth. Radha-Krishna being situated in Chaitanya's own person, their flute-romance is fused with his breathing body.

In the kirtan's second part, the flute is explicitly connected to Krishna's persona, indistinguishable from his erotic divinity. Radha curses the flute which has maddened her auditory pleasures by singing her name, driving her out of home at night to the forestbowers, and whose sounds are like the lustful stings of a poisonous snake. She says that the flute carries Krishna's magic spell and bites away her worldly attachments. These are erotic representations of the flute as Krishna's lustful embodiment, whose passionate fifth note sings for Radha. The licentious snake reminds of the body's feminine, serpentine power, awakened by Krishna-love, and hissing AUM nada. Radha further says that she and Krishna are located on two banks of the Yamuna river, and the flute invites her to swim across. Musicians explained that this again is reminiscent of kundalini as Radha shakti, at one end of the body (anus), moving upward (cranium) to meet Krishna, when she responds to the flute call. In tantric cosmology, during this reverse direction, the body's feminine force embodies spiritual maleness (pungsvarupini) or a transcendental mood away from material life, in order to become him, or unite in absorption. From Radha's temper (paradigmatic for devotees) of intense separation from Krishna, when stimulated by his flute sound, she gradually apprehends the sense of becoming one with the flute/Krishna.

Radha then asks Krishna the following questions in Bongshi Shikkha-what tune do you fill in each pore; which pore-tune makes the river Yamuna flow in reverse; which one attracts Radha like a mad lover; which makes flowers blossom, and which makes Radha lose her virginity? Krishna asserts that to understand these, she must 'become him': look and dress like him, and be male-(like). He first teaches her about the characteristics of his three flutes (exactly as described in Bhaktirasamrita Sindhu), and then answers her questions: the first pore-tune awakens gods; the second causes Yamuna's reverse flow, its waters washing Krishna's feet with love; the third makes winds halt; the fourth drives 
all Vrindavan women crazy with passion; the fifth hole attracts cows; hearing the sixth pore-note flowers blossom and all seasons assemble; the seventh is so sharp that it melts stone, and the eighth pore pointedly addresses Radha. This eighth pore sounds the fifth melody-note with Krishna shutting all holes with his fingers and blowing on the ninth mouth-hole. This is the counterpart of the body shutting its outlets and turning breath inward to sound Krishna's flute-love. The Brihat-Krishnalila-Saravali adds that the flutes also play according to times of the day. Therefore, the murali plays when Yashoda, Krishna's mother, cooks for him, the venu, when he grazes cows, and the nine-holed vamsi, when he entices women lovers, especially Radha (Ghosh 2018, p. 411).

Krishna confesses to Radha that without understanding the flute, all knowledge remains facile. After learning the theory from him, when Radha physically begins to play the flute, Krishna describes how she fuses exactly with the instrument, her golden fingers blending with the golden flute; and then as she blows on its pores, she literally becomes Krishna, he says. Radha then plays the fifth flute note, which in turn invites Krishna, as it initially captivated her. On Krishna's lips it sings for Radha, and vice versa. This is therefore a most nuanced narrative about the reflective equivalence of devotee-fluteKrishna, recognised by cultivated bodies as male-female energies united within itself, and the flute calling out Radha's and Krishna's names through its fifth note implying the passionate corporeal bliss within the devotee's yogic body. In tantric terms, this is essentially about bodily male-female vitalities unitedly flowing upwards and throbbing with breath $/ \mathrm{AUM}^{*}$ / flute nada. Radha-Krishna thus unite, and the flute sounds, within the same corpus, signify complete blending of devotee-instrument-god, while without the sense of their initial distinctness in the first instance, any aesthetic theology is impossible.

\subsection{Chaitanya Charitamrita}

The devotee-flute-divinity complex of sameness and difference also comes alive in episodes of Chaitanya Charitamrita. In the fourteenth chapter of its Madhya Lila, an assemble of devotees that commemorate gopis' love for Krishna. Chaitanya requests one of them, King Prataparudra, to recite verses from Gopi Gita (31:9) describing Krishna's lower lip as filling meaning in the world of words, sound, and eros, while blowing into his flute. Hearing these verses, Chaitanya and devotees are caught in ecstasy, their skin oozing goosebumps, and their eyes, tears (3-11 cited in Stewart 1999, pp. 534-35). In chapter sixteen of Antya Lila, Chaitanya visits the deity Jagannath/Krishna in Puri, and has a vision of him with a flute on his lips (80). The temple guards then offer him prasad, food offerings tasted by the deity, and its nectar-like sweetness completely enamour Chaitanya, who marvels at the taste leftover by Jagannath's lips (81-94 cited in ibid: 952-53). Returning home, he keeps meditating on those lips even amidst his daily chores, and shares the prasad with all devotees, who collectively realise the intoxicating power of anything touched by Krishna's adhara (lower lip). Chaitanya then requests a devotee to recite verse 14 of Gopi Gita, which describes Krishna's lip-nectar kissed by the flute, thus producing the fifth note which destroys all suffering and intensifies blissful desire (109 cited in Stewart 1999, p. 953). Chaitanya also remembers a verse where Radha describes Krishna's lips as arousing her tongue's desire (Govindalilamrta 8.8:10, cited in ibid: 954). Such an intense wish to taste the taster subtly pre-empts the devotee-god's dialectic of separation and union, longing and fusion, since when the tongue locks the lip, the two are both distinct and not, their embrace however amplifying the pleasures of both.

The devotees (in gopis' mood) continue to praise Krishna's lips, which cause everything to become inverse (113 cited in Stewart 1999, p. 954). This reversal implies devotees' turning away from material pleasures towards the divine, or the pulling up of breathenergy within the body from the downward-facing feminine forces, upward towards cerebral consciousness. Further, devotees sing, the lips make unconscious things conscious, here referring to the flute, whose sound, Krishna's breath, and all spiritual meaning fuse, to constitute rasa (aesthetic essence). The flute thus gains life and sense (115 cited in ibid). 
Sound is thus direct divine eros, and knowledge, aesthetics, taste, and philosophy are literally breathed through Krishna's flute.

The text then takes complex turns. As in Gopi Gita and Venu Gita, the devotees are envious of the flute, which drinks with passion the nectar that they deserve. However, the flute also challenges them, saying that if they unite with Krishna, leaving their shame, families, and worldly attachments, then it will give up its position to them. Certain complications are noteworthy. The flute is literally described as a male entity here, and thus taking up the flute's position implies 'becoming male' to 'become the flute'. As discussed before, becoming male has yogic implications of breath's reverse flow, carrying kundalinienergy towards Krishna-cranium, responding to the flute's call stuck to Krishna's lip. In this mood, a devotee recites Venu Gita, verse nine: asking, what kind of austerities, chanting of mantras, etc. must the flute have performed, to become conscious from unconscious, and despite being male, enjoy the nectar that women heatedly desire (130-34 cited in Stewart 1999, pp. 956-57). This clearly directs towards ascetic practices devotees should cultivate to become the flute, the 'fruit of such asceticism' (135 cited in ibid) being divine erotic breath-sound. While devotees call the flute unworthy of Krishna's love since it is inanimate and masculine (134 cited in Stewart 1999, pp. 956-57), paradoxically, they wish to 'learn the flute's ascesis', in order to realise Krishna (139 cited in Stewart 1999, p. 958). This contradiction is telling, since while in classical aesthetics, Bengal Vaishnava devotees cultivate a feminine persona in the sringara (love)-mood to unite with Krishna, its yogic-tantric temperament also implies the pung-svarupini (male-personified) direction of one's feminine identity, or turning from downward facing material energy (prakriti) towards the upward eternal male consciousness (purush).

A lore recounted in Brihat-Krishnalila-Saravali, the compilation of Bhagavatam's tenth part narrative combined with oral traditions, also embodies the flute's male-female dichotomy, through a popular belief. It says that, witnessing Krishna-Radha's intense love, the goddess Saraswati is jealous, and desires Krishna's lip-rasa (taste/aesthetics). She renounces the heavens to perform severe austerities to achieve this. All scriptures and sages then lose their abilities of utterance, with the goddess of sound and speech having disappeared. She is finally awakened from her concentrated meditation by Vishnu's conch-echo, and he promises to keep her within his very own flute. He tells her that she would obtain his fullest lip-nectar, and only her leftovers shall be consumed by Radha and other lovers. He adds that she would be present in Vrindavan's bamboo trees on the river Yamuna's banks, from which the flute would be born, and thus always be closest to Krishna, adorning his hands and mouth. Radha would indeed be bewitched by Saraswati's own sonic powers. He then requests her to return to the heavenly world of speech (Ghosh 2018, pp. 411-13). While this narrative may seem contradictory to Chaitanya Charitamrita's imagination of the flute as male, yogic imagination ties them. Sound-meditators thus explained to me that Saraswati is directly representative of feminine kundalini energy, ${ }^{17}$ the sleeping conch-like coiled force, who when awakened rises through the anus, navel, chest, and throat (tantric centres of speech-emanation), sounding her powers, including as speech. Her 'rising up' to Krishna however embodies her male-facedness. In other readings, Radha herself is the kundalini/Saraswati divinity, deriving her powers from Krishna's lips, and sounding purush/transcendence (see below).

Chaitanya Charitamrita thus animates the nuanced interface of devotee-flute difference, difference-led envy transforming to a yogic/monist sense of ascetic sameness, the body's desire to become the flute, and further, the devotee-flute's intense embroilment with the divine lips as both different and same (achintya-bhed-abhed), thus alternating between Krishna as subject blowing on the body-flute, and body-flute as subject tasting Krishna. This is further compelling since the entire theology is realised by Chaitanya, whose own body houses the union of Radha-Krishna, and thus the flute-devotee-god. Additionally, following the Brihat-Krishnalila-Saravali story, Saraswati cannot remain in silent meditation (ashabda), since that would imply complete monist absorption and no vibration at all, and thus Narayana requests her to return speech. The devotee/feminine energy must be in an 
always productive relation of sameness and difference with the divine/male energy-like the flute-lip-lock- to be able to sound incessant cosmic love.

\subsection{Oral Traditions}

Oral traditions also preserve other direct references to Radha-Krishna-flute vibrations within the devotee's body. Therefore, a kirtan percussionist, and a Bengal Vaishnava practitioner for over sixty years, narrated to me a very rare poem about the flute, which he had received from his Vrindavan guru. The poem effectively combines yogic/tantric thematics of sonic metaphysics with Vaishnava devotional affect, by correlating corporeal locations with aesthetic descriptions about Vrindavan's places, divinities, and their romance. Here, kundalini (Radha) travelling up the reverse flow of Yamuna (from lower to upper body chakras) to meet Krishna, essentially summarises the intense bodily affectivity informing Bengal Vaishnava flute experiences and demonstrates the Yoga-Tantra-devotion ensemble of popular thought.

The sharp flute is playing, calling out to Radha

Her eyes are lazy and sleepy (it is night)

On hearing Krishna's sound, Rai (Radha)-Kundalini is awakened

At the tip of the sahasrara (cranium-chakra), on the banks of Yamuna, the flute plays on Krishna's lip-lotus

Attracted by the sound of his incomparable love, all three worlds are maddened

The buzz rushes down to muladhara (anus-chakra), and the yet-sleeping Kundalini-Rai wakes up Krishna

Energised, excited, and with an anxious, awaiting heart, she dashes up towards

Slowly, leaving ira on the left, and pingala on the right, and taking up the middle path of sushumna, she roars in the muladhara ${ }^{18}$

She responds to nasal flute tones sounding like klim (Krishna's seed-syllable)

...

Like buzzing bees over sweet flowers

Like the hamsa (AUM) bird in love

Rai passes through svadhishthana (genital-chakra) lotus

$\ldots$

She comes to manipur (navel-chakra), at the ten-petalled lotus floating on the passionlake

She enters the heart (chakra) at the twelve-petalled lotus

...

And experiences ecstatic possession

...

She goes up to vishuddha (throat chakra) with other friends

Then reaches agya-pura (middle-of-eyebrows chakra), at the two-petalled lotus where the tilak (Vaishnava religious sandalwood-mark made on forehead) is drawn

And finally rushes up to sahasrara

Where sitting under a beautiful tree on the river banks, Shyam (Krishna) plays his bewitching flute

He is like a newly formed, dark, wet cloud, whom Rai embraces like lightning. ${ }^{19}$

\section{Conclusions}

Bengal Vaishnavism's conceptualisation and experience of Krishna's flute sound lies at the confluence of yogic, tantric, and aesthetic devotional thought. Unlike yogic traditions of sonic bodily cultivation in which full emptiness (ashabda) - beyond all sound —is the aspired goal of the corporeal being, theistic Nada-Yoga traditions understand the ultimate spiritual experience as transcendental sound. In Bengal Vaishnavism this translates as Krishna playing his flute. Although Yoga unequivocally situates all levels of sacred experience 
within the body, there is a subtle transition in the final stages of acoustic apprehension. In the penultimate stage, therefore, the flute is sensed as merged with one's vital breath-air, and thus Krishna may be imagined here as situated inside the body, fused with the devotee's self, and blowing his flute with/in the practitioner's whistling breath, sonically tuned to the fifth flute note. The fourth, transcendental stage, however, refers to perceived/unrealised vibration, and may be thought of as Krishna, the shining witnessing self, including, though surpassing levels of physical sensation and cognition, and incessantly blowing on his flute. This level may thus be understood as within the body, as equally, a macrocosmic force outside. It is precisely this dialectic of inside-outside, monism-dualism, which drives the Bengal Vaishnava imaginations of relations among the devotee, flute, and Krishna; best embodied by Krishna's lip-lock with his beloved flute, since it is impossible to imagine whether the entangled lip and flute are separate or indistinct.

Bengal Vaishnava texts thus make effective allusions to yogic notions of oneness: between devotee-flute through breath-sound relations, devotee-god, and Krishna-flute; as well as ideas of difference between devotee-flute-god, since for them, the ontology of difference is most real, and without it, aesthetic relish is impossible. Thus, senses of indistinction between the devotee and god are as critical as their affective distance. These debates are recast in narrative forms, as stories of union between Krishna-devotee-flute, or their intense separation. Classical and popular texts thus have references to Krishna playing the flute, his inseparable body part, to invite Radha (devotee) to unite with him; Radha being envious of the privileged flute, essentially separate from her, desiring to comprehend its ascetic virtues, and then, however, becoming the flute to stick to Krishna's lip and receive his warm breath; devotee and flute vying for Krishna's lip-love, as well as oral narratives about Radha-Krishna uniting, and the flute then sounding. These varied narrative instances are also implicit references to yogic practices of asceticism, unifying cosmic male-female energies inside the body, realising breath-sound translations, the body becoming the austere/emotive flute, becoming god, etc., as also realising real difference from them. In yogic/tantric idioms, with the practitioner's constant utterance of AUM, its tapering nasal buzz becomes the flute hum (in the anus region) and arouses the body's feminine energy to unite with Krishna, and again, in uniting with him, the flute resounds (in the cranial region). The Gita-described nine-pored body then fuses with the god-flute ('madbhavam' state), and this yogic discourse ties up with Bhagavat's devotional aesthetics of the devotee-becoming-full-of-god ('tat-mayatam' state) through passionate absorption in his thoughts, either in separation or union. Yoga and aesthetics, sameness and difference, thus combine, in the peculiar Bengal Vaishnava theological imagination of achintya-bhed-abhed, through sophisticated arousals of flute melody.

Funding: This research received no external funding.

Institutional Review Board Statement: Not applicable.

Informed Consent Statement: Informed consent was obtained from all subjects involved in the study.

Conflicts of Interest: The author declares no conflict of interest.

\section{Notes}

1 This is attested by Krishna's various names: Vamsidhar, Muralidhar, Venugopala, etc., vamsi, venu, murali being names of his flutes; while names like Mohan (enchanter) and Krishna (all-attractor) embody his desirable flautist self.

2 One of Krishna's flutes is known as nasajantra, the nose flute, and the 13th century Sanskrit text on music, Sangit Ratnakara, cites flute-names which correspond to the body's yogic chakras. See https:/ / www.theosophytrust.org/728-flute (accessed on 27 July 2021).

3 The body's nine openings are: pair of eyes, ears, nostrils, the mouth, anus, and genitals.

4 In Indian classical music, the fifth note, panchama, is the fifth position (svara) in an octave (saptak) of seven notes, and has a singular tonal representation, unlike notes which may have different frequencies (komal/tivra). 
All references are given later. See also Rupa Goswami's poem composition describing the flute's fifth note. http://www. purebhakti.com/teachers/bhakti-Yoga-masters/775-srila-rupa-gosvami-svarupasanatana (accessed on 27 July 2021).

6 See https:/ / sreenivasaraos.com/2015/04/27/music-of-india-a-brief-outline-part-nine/ (accessed on 27 July 2021).

7 The story recounts that Ram's bamboo bow became Krishna's bamboo flute. Bamboo reported to Ram that sage Parashuram had put up a challenge: the one who would be able to break his bamboo bow into half could marry the great princess of earth, Sita. Bamboo allowed itself to be broken only by Ram however, and thus united him with Sita in marriage. Ram felt indebted, and so granted him his wish of always being close to his eternal Narayan form: thus, in his next birth as Krishna, he promised that bamboo would stick to his intimate lips, sucking divine nectar, and spreading divine pleasure to all (Ghosh 2018, pp. 200-3).

8 Such male-female union is often represented as Shiva-Shakti in later tantric traditions, and Krishna-Radha in Vaishnava ones.

9 See http://www.advaita.it/library/nadabindu.htm (accessed on 27 July 2021).

10 The flute is also mentioned as a higher sound experience in Kaulajnana-Nirnaya by Matsyendranath (14.85-6 cited in Beck 1995, p. 99), to whose sect belongs the classic Yoga text, Hathayoga Pradipika, discussed below.

11 See also http:/ / www.rupanuga.narod.ru/pdf/gitas_en.pdf (accessed on 27 July 2021).

12 Elsewhere in the text, the gopis express that the flute's sound nectar has ignited the greatest passions in them (10: 29.34, 40 cited in Schweig 2005, pp. 26, 35, 37).

13 See also http:/ / www.harekrsna.de/artikel/gopi-gita.pdf (accessed on 27 July 2021).

14 Krishna Virudavali describes the two sparkling earrings on Krishna's ears as bindu (purush) and visarga (prakriti), with an adenoidal ring, and his indistinct sweet voice as also nasal in tone (Goswami 1944, p. 44). This denotes Krishna himself as the unified form of purush-prakriti, and his immediate embodiment, the flute, as ringing anahata nada, or the AUM buzz fading with the nasal drone.

15 Sahajiya Vaishnavism is a Bengal Vaishnava sect which utilises yogic-tantric methods directly. Their rare texts detailing practices mention that during yogic pranayama, breath-air violently undulates in the chakra-region between genitals and middle of eyebrows, since the feminine energy, snake kundalini, then responds to anahata nada sounding as Krishna's flute in the cranium, and hisses up to meet him. In Sahajizas' fourfold division of corporeal states with accompanying practices and bodily sensations, the final one (siddhir desh) embodying male-female union and sexual-spiritual bliss, is characterised by the chief 'excitant' (uddipan), bongshi dhvoni, flute-drone, humming in the head (Chakrabarti 1940, pp. 11, 21; Das n.d., p. 125).

16 An example of a Bongshi Shikkha episode may be found here: https:/ /www.youtube.com/watch?v=5MtDP7j1Rbg (accessed on 27 July 2021).

17 The mantric seed-syllable corresponding to the worship of both kundalini and Saraswati is oing.

18 There are three main spinal channels in the yogic anatomy: ira, pingala, and the main central, purified nerve, sushumna, through which the practitioner pulls up vital breath. All chakras along the spinal cord are imagined as lotuses with specific numbers of petals.

19 Tantra texts like Guru Gita (part of Visvasara Tantra), also describe kundalini as the most subtle lightning-like illuminated serpentine force, which coils at the spinal base, and shoots up through the body (Saraswatananda 2015, p. 52).

\section{References}

Ayyangar, Srinivasa T. R., trans. 1938. The Yoga-Upanisads. Madras: The Adyar Library. Bandopadhyay, Sureshcandra, ed. 1995. Bharata Natyashastra. Calcutta: Nabapatra Prakashan.

Beck, Guy L. 1995. Sonic Theology: Hinduism and Sacred Sound. Delhi: Motilal Banarsidass Publishers Private Limited.

Beck, Guy L. 2013. Bhakti Sangit: The Art of Music in Vaishṇava Tradition. Journal of Vaishnava Studies 21: 143-71.

Translated and Edited by Mandakranta Bose. 2009, Sangitanarayana (A Seventeenth Century Text on Music and Dance from Orissa) by

Purusottama Misra. New Delhi: Indira Gandhi Centre for the Arts and Motilal Banarsidass Publishers Pvt. Ltd., vol. 1.

Brahmachari, Mahanambrata. 1994. Vaisnava Vedanta. Calcutta: Sri Mahanambrata Cultural and Welfare Trust.

Chakrabarti, Haridas. 1940. Panchatattva O Gynamrita Katha. Navadvip: Sri Devimadhava Chakrabarti.

Das, Vaishnava. n.d. Krishnatattvarasamrita Jnanmanjari. Kolkata: Rajendra Library.

Deva, Bigamudre Chaitanya. 1977. Musical Instruments. New Delhi: National Book Trust.

Dimock, Edward C. 1963. Doctrine and Practice among the Vaisnavas of Bengal. History of Religions 3: 106-27. [CrossRef]

Ghosh, Radhamadhav. 2018. Brihat Krishnalila Saravali. Kolkata: Akshay Library.

Goswami, Krishnacharan. 1944. Sri Sri Krishnavirudavali. Navadvip: Horibol Kutir.

Gupta, Ravi. 2007. The Caitanya Vaisnava Vedanta of Jiva Goswami: When Knowledge Meets Devotion. London and New York: Routledge.

Haberman, David L. 2003. The Bhaktirasamrtasindhu of Rupa Goswami. New Delhi: Indira Gandhi National Centre for the Arts and Motilal Banarsidass Publishers Pvt. Ltd.

Krishnaswamy, Subrahmanyam. 1965. Musical Instruments of India; New Delhi: Publications Division, Ministry of Information and Broadcasting, Government of India.

Marriott, McKim. 1976. Hindu Transactions: Diversity without Dualism. In Transaction and Meaning: Directions in the Anthropology of Exchange and Symbolic Behaviour. Edited by Bruce Kapferer. Philadelphia: Institute for the Study of Human Issues. 
Marriott, McKim. 1989. Constructing an Indian Ethnosociology. Contributions to Indian Sociology 23: 1-39. [CrossRef]

Muktibodhananda, Swami, trans. and ed. 1993. Hatha Yoga Pradipika. Munger: Yoga Publications Trust.

Omkarnathdev, Sitaramdas. 1990. Sri Omkarnath-Rachanavali. Kolkata: Akhil Bharata Joyguru Sampraday, vol. 10.

Padoux, Andre. 1992. Vac: The Concept of the Word in Selected Hindu Tantras. Delhi: Sri Satguru Publications.

Pande, Anupa. 1996. Abhinavabharati (Abhinavagupta's Commentary on Bharata's Natyashastra Chapter XXVIII: English Translation with Historical Critical Explanations). Allahabad: Raka Prakashan.

Saraswatananda, Swami. 2015. Diksha Prasanga, Guru Gita O Bani. Kolkata: Bharat Sevasram Sangha.

Saraswati, Bhaktisiddhanta. 1975. Srimad Bhagavatam, Tenth Canto. Mayapur: Nadia Prakash Printing Works.

Schweig, Graham M. 2005. Dance of Divine Love: The Rasa Lila of Krishna from the Bhagavata Purana, India's Classic Love Story. Princeton and Oxford: Princeton University Press.

Sinha, Kaliprasanna. 1987. Mahabharata. Tulikalam: Kolkata, vol. 2.

Srimad, Arirban. 1992. Upanishad Prashanga. Fifth Part: Kaushitaki Upanishad. Bardhhaman: University of Bardhhaman Press.

Stewart, Tony K., ed. 1999. Caitanya Caritamrta of Krishnadas Kaviraja: A Translation and Commentary by Edward C. Dimock Jr.. Cambridge: Harvard University Press.

Stewart, Tony K. 2010. The Final Word: The Caitanya Caritamrita and the Grammar of Religious Tradition. New York: Oxford University Press.

\section{Weblinks referred to (in order of appearance):}

Theosophy Trust Memorial Library. The Flute. Available online: https:/ / www.theosophytrust.org/728-flute (accessed on 27 July 2021).

Srila Rupa Goswami. Available online: http://www.purebhakti.com/teachers/bhakti-Yoga-masters/775-srila-rupa-gosvamisvarupasanatana (accessed on 27 July 2021).

Musical Instruments in Natyashastra (including sections of Abhinavabharati). Available online: https://sreenivasaraos.com/2015/04/27 / music-of-india-a-brief-outline-part-nine/ (accessed on 27 July 2021).

Aiyar, Narayanswamy (translated). Nada-Bindu Upanishad. Available online: http:/ / www.advaita.it/library/nadabindu.htm (accessed on 27 July 2021).

Iyer, Raghavan. 1977. The Flute of Krishna. Available online: https:/ / www.theosophytrust.org/795-the-flute-of-krishna (accessed on 27 July 2021).

Venu-Gita (The Gopis Glorify the Song of Krsna's Flute). Srimad Bhagavatam-10.21.1-20. Available online: http:/ / www.rupanuga.narod.ru/ pdf/gitas_en.pdf (accessed on 27 July 2021).

Gopi-Gita (The Gopis' Song of Separation). Srimad Bhagavatam-10.31. 1-19. Available online: http://www.harekrsna.de/artikel/gopi-gita. pdf (accessed on 27 July 2021).

Bhattacharya, Suman. 2018. Bongshi Shikkha (kirtan performance). Available online: https://www.youtube.com/watch?v=5MtDP7j1Rbg (accessed on 27 July 2021). 